С. А. Бузько

\title{
ФОРМУВАННЯ МОВЛЕННСВОЇ КУЛЬТУРИ СТУДЕНТІВ ПІД ЧАС ВИВЧЕННЯ ДИСЦИПЛІНИ «УКРАЇНСЬКА МОВА (ЗА ПРОФЕСІЙНИМ СПРЯМУВАННЯМ)»
}

\begin{abstract}
Бузько С. А. Формування мовленнєвої культури студентів під час вивчення дисципліни «Українська мова (за професійним спрямуванням)».

У статті обгрунтовано зв'язок культури мовлення студентів із вивченням дисципліни «Українська мова (за професійним спрямуванням)». Цей курс передбачає не лише вироблення в майбутніх спеціалістів професійно зорієнтованих умінь і навичок досконалого володіння українською літературною мовою у фаховій сфері, але й підвищення загального мовно-культурного рівня, удосконалення мовної майстерності, вироблення навичок вільного й невимушеного володіння літературною формою загальнонародної мови в найрізноманітніших комунікативних ситуаціях. Наголошено на тому, що одне 3 основних завдань цієї навчальної дисципліни - формування мовленнєвої культури, яка є індикатором загальної ерудиції людини, особливостей іï інтелекту, соціального статусу. Запропоновано зразки завдань, які підібрано 3 урахуванням мовної ситуації в України (українсько-російського білінгвізму).

Ключові слова: культура мовлення, мовленнєва культура, українська
\end{abstract} літературна мова, комунікативна ситуація.

Бузько С. А. Формирование речевой культуры студентов во время изучения дисциплины «Украинский язык (профессионального направления)».

В статье обосновывается связь культуры речи студентов с изучением дисциплины «Украинский язык (профессионального направления)». Этот курс предусматривает не только вырабатывание у будущих специалистов профессионально ориентированных умений и навыков свободного и непринужденного общения на украинском литературном языке в профессиональной сфере, но и повышение общего культурного уровня, а также усовершенствование языкового мастерства. Акцентируется внимание на том, что одно из главных заданий этой учебной дисциплины - формирование речевой культуры, которая есть индикатором общей эрудиции человека, особенностей его интеллекта, социального статуса. Предлагаются образцы заданий, которые подобраны с учетом языковой ситуации в Украины (украинско-русского билингвизма).

Ключевые слова: культура речи, речевая культура, украинский литературный язык, коммуникативная ситуация.

Buzko S. A. Forming of students' speech culture during studying of course "Professional Ukrainian language".

The article is devoted to the actual problem of the formation of youth's speech culture, in particular students', since the younger generation defines the vectors for the further development of any society. The connection between students' speech culture and 
their learning of subject "Professional Ukrainian language" is grounded. This course includes not only forming of professionally oriented skills of mastery of the Ukrainian literary language in professional sphere, but acculturating, advancing of speech mastery, forming of oral and written fluency in literary form of Ukrainian language in different communicative situations. The author stresses that one of the main tasks of this course is forming of speech culture that is the marker of person's general knowledge, peculiarities of his / her intelligence, social status. Examples of tasks proposed for students during studying the course. The tasks are selected taking the linguistic situation in Ukraine into account (Ukrainian-Russian bilingualism is meant).

The task of forming the language culture of students is solved by a specially selected complex of tasks and exercises, provided for both classroom and independent work. The article suggests some examples of tasks, the implementation of which helps students to master modern linguistic norms, improve their linguistic preparation, and, consequently, the level of speech culture. All proposed tasks are tested. A number of exercises are related to the comparison of certain grammatical structures in the Russian and Ukrainian languages. Students are offered the exercises for grammatical analysis, translating of structures with prepositions, selecting of a normative variant, editing of sentences with logical distortion, explaining of the meanings of paronyms, putting words into the context, selecting Ukrainian equivalents to borrowed words.

Key words: speech culture, Ukrainian literary language, communicative situation.

Культура мовлення - проблема, яка так чи так стосується будьякої національної спільноти і є предметом уваги не лише лінгвістів, а й узагалі всіх людей, що піклуються про престиж своєї мови. Особливо актуальною нам видається проблема мовленнєвої культури сучасної молоді, зокрема студентства, адже саме молоде покоління, як відомо, визначає вектори подальшого розвитку будь-якого суспільства. Кожен, хто прагне досягти успіху, неодмінно має володіти культурою мови (мовлення), яка є свідченням того, як особистість створює навколо себе своєрідну вербальну ауру, що формує мовний сак чи несмак. Зазвичай терміни «культура мови» і «культура мовлення» використовують як синонімічні й у двох значеннях - як уміння дотримуватися усталених норм усної і писемної форм літературної мови і як мовознавча дисципліна. Як лінгвістична наука, культура мови (мовлення) вивчає стан і статус (критерії, типологію) норм літературної мови в конкретну епоху, а також рівень лінгвістичної компетенції сучасних мовців [5, с. 7]. За свідченням лінгвістів, на сучасному етапі розвиток культури мови позначений впливом антропоцентризму (сприйняття людини як найвищої цінності) i характеризується підвищеною увагою до комунікативного компонента. Це виявляється в орієнтації культури мови як науки на формування креативної мовної особистості, яка має 
розвинуте чуття мови, досконало володіє мовним етикетом і спрямована на толерантне мовленнєве спілкування.

Формуванням культури мовлення студентів як умінням володіти літературною мовою в різних комунікативних ситуаціях, зокрема й у фаховій сфері, займається навчальна дисципліна «Українська мова (за професійним спрямуванням)». Цей курс передбачає не лише вироблення в майбутніх спеціалістів професійно зорієнтованих умінь і навичок досконалого володіння українською літературною мовою у фаховій сфері, але й підвищення загального мовно-культурного рівня, удосконалення мовної майстерності, вироблення навичок вільного й невимушеного володіння літературною формою загальнонародної мови в найрізноманітніших ситуаціях спілкування [7, с. 7]. Одне 3 основних завдань цієї дисципліни ми вбачаємо у формуванні мовленнєвої культури, яка є індикатором загальної ерудиції людини, особливостей іiі інтелекту, соціального статусу, тобто фактично візитівкою особистості в суспільстві. Реалізації цього завдання сприяє спеціально підібраний комплекс завдань і вправ, передбачений як для аудиторної, так і для самостійної роботи. Пропонуємо приклади деяких завдань, виконання яких допомагає студентам опанувати сучасні мовні норми, підвищити рівень своєї мовної підготовки, а отже, й рівень мовленнєвої культури. Усі пропоновані завдання апробовані на нефілологічних факультетах Криворізького державного педагогічного університету під час вивчення дисципліни «Українська мова (за професійним спрямуванням)». Для виконання цих завдань радимо студентам користуватися відповідними посібниками та словниками, наприклад, такими, як «Українська мова для всіх» [1], «Культура слова : Мовностилістичні поради» [6], «Як правильно говорити українською» [3], «Словник труднощів української мови» [2] та ін. Деякі вправи пов'язані із зіставленням певних граматичних структур російської та української мов. Вибір таких завдань зумовлений мовною ситуацією України й тими умовами, у яких існує наше суспільство (маємо на увазі українсько-російський білінгвізм). Адже, як засвідчують соціолінгвісти, мовну ситуацію нашої країни характеризує українсько-російська двомовність [4, с. 25], що ми й намагалися враховувати під час розробки вправ і завдань.

Завдання 1. Уважно прочитайте подані конструкиії, зверніть увагу на граматичну форму залежного компонента в обох мовах, визначте відмінок; з п'ятьма словосполученнями складіть речення. 
Изменить (кому? чему?) принципам - зрадити (кого? що?) принципи; подражать (кому?) актеру - наслідувати (кого?) актора; причинять (что?) беспокойство - завдавати (чого?) клопоту; снабжать (чем?) товарами -постачати (що?) товари; сообщить (кому?) учителю - повідомити (кого?) вчителя; учиться (чему?) музыке - вчитися (чого?) музики; оповестить (кого?) соседей сповістити (кому?) сусідам; прилагать (что?) усилия - докладати (чого?) зусиль; прибегнуть (к чему?) к хитростям - вдатися (до чого?) до хитрощів; воспользоваться (чем?) случаем - скористатися (з чого?) 3 нагоди; дать определение (чему?) термину - дати визначення (чого?) терміна; потерпеть (что?) неудачу - зазнати (чого?) поразки; смеяться (над кем?) над ними сміятися (з кого?) з них; болеть (чем?) гриппом - хворіти (на що?) на грип; подобный (чему?) туману - подібний (до чого?) до туману; обращаться (за чем?) за помощью - звертатися (по що?) по допомогу; приняться (за что?) за работу взятися (до чого?) до роботи; жениться (на ком?) - одружуватися (з ким?); прийти (к чему?) к выводу - дійти (чого?) висновку; овладеть (чем?) знаниями опанувати (що?) знання; оволодіти (чим?); занимать (что?) четкую позицию триматися (чого?) чіткої позиції; заострить внимане (на чем?) на мелочах звернути увагу (на що?) на дрібниці; знать толк (в чем?) в искусстве - розумітися (на чому?) на мистецтві; пойти по направлению (к чему?) к лесу - попрямувати (до чого?) до лісу; извините (кого?) меня - пробачте, вибачте (кому?) мені; испытывать нужду (в чем?) - потребувати (чого?); положить (что?) все силы докласти (чого?) всіх зусиль; метать (что?) искры - сипати (чим?) іскрами; нанести (что?) вред - завдати (чого?) шкоди; наступить на горло (кому?) - взяти за горло (кого?); находить удовольствие (в чем?) в отдыхе - тішитися (чим?) відпочинком; находиться в противоречии (с чем?) - суперечити (чому?).

Завдання 2. Перекладіть подані конструкиії з російської мови на украӥнську, зверніть увагу на вживання прийменників у обох мовах.

Без запинки; без исключения; без промедления; без умолку; в дальнейшем; в данное время; в двух словах; вступить в должность; в заключение; в здравом уме; в изобилии; в изумлении; в конечном итоге; в лучшие времена; в надежде на что; в один голос; во что бы то ни стало; в первую очередь; в сущности; в противном случае; взять себя в руки; в силу изложенного; в скором времени; для вида; до сих пор; из ряда вон выходящий; на голодный желудок; на ночь глядя; на редкость; на рубеже векав; от безделья (от нечего делать); по взаимному согласию; по всей вероятности; по воскресеньям; по доброй воле; по душам (поговорить); по имеющимся сведениям; по крайней мере; по левую руку; по мере надобності; по местам!

Завдання 3. Виберіть $i$ запишіть правильний варіант слововживання:

Військова чи воєнна частина? Поверхові чи поверхневі знання? Музична чи музикальна школа? Музичний чи музикальний слух? 
Екзаменаційний білет чи квиток? Твоє ставлення чи відношення до мене? Пам'ятка чи пам'ятник архітектури? Житель чи мешканець будинку? Очі закрити чи заплющити?Вікно закрити чи зачинити? Поверхові чи поверхневі води? На літак квиток чи білет? Передвиборча кампанія чи компанія?

Завдання 4. Виберіть $і$ запишіть нормативний варіант поданих мовних зворотів.

Розділяти поняття - розмежовувати, диференціювати; ряд праць - низка праць; розходження в поглядах - розбіжності в поглядах; складати частину становити частину; служити підставою - бути підставою, слугувати підставою; смисл життя - сенс життя; справа в тому - річ у тім; становить собою - являє собою; тим не менше - проте, однак, попри це; типу - на зразок, на кшталт, на взірець; у деякій мірі - деякою мірою; у значній мірі - великою мірою; у першу чергу - насамперед, передовсім, найперше; у разі необхідності - у разі потреби; у той же час - водночас; у цілому - загалом; у цьому відношенні - щодо цього, у цьому плані; через деякий час - згодом, незабаром, невдовзі; як правило переважно, здебільшого, зазвичай; понятійний - поняттєвий; піднімати питання - порушувати питання; при вивченні - у процесі (під час) вивчення; при необхідності - за потреби; протиріччя - суперечність; разом із тим - водночас.

Завдання 5. Знайдіть у реченнях порушення логічності; відредагуйте речення й аргументуйте виправлення.

1. Кожний герой має свої індивідуальні риси; 2. Шевченко подружився 3 новими друзями; 3. На вулиці було чути крик дитячих голосів; 4. Вона дуже любила ангорських кішок і собак; 5. Захист курсових робіт відбудеться у квітні місяці; 6. Сьогодні політ у небесні далі людини став реальною дійсністю; 7. Мати веде двох маленьких, гарно одягнених і сірооких дівчаток; 8. I вони,з опущеними вниз оченятами, боязко дивились на неї; 9. Маю надію сподіватися, що наша передача принесла вам приємні хвилини; 10. Його попросили написати свою автобіографію детальніше.

Завдання 6. Пояснити значення наведених слів, склавши з ними словосполучення або речення.

Екземпляр - примірник; передплата - підписка; дільниця - ділянка; привласнювати - присвоювати; тактовний - тактичний; свідоцтво - свідчення - посвідчення; церемонний - церемоніальний; практик - практикант; пам'ятка - пам'ятник; поверховий - поверхневий; абонент - абонемент.

Завдання 7. Розкрийте дужки, утворюючи словосполучення.

Школа, слух (музичний, музикальний); (житель, мешканець) будинку, України; (квиток, білет) на потяг, на екзамені; (ставлення, відношення) до людей, між людьми; (пам'ятка, пам'ятник) архітектури, Т. Шевченку; (дефекти, недоліки) у роботі, у приладі; військовий, воєнний (дії, частина); поверховий, поверхневий (води, знання); усмішка, посмішка (привітна, іронічна). 


\section{Завдання 8. Виправте помилки в поданих мовних зворотах.}

По бажанню; по вині; по вказівці; по дорученню; згідно наказу; опанувати мовою; використовувати по призначенню; завідувач відділом; завідуючий кафедри; відповідно наказу; уникати небезпеку; відповідно меті; набувати досвід; запобігати помилок; властивий для твору; надавати вигляд.

Завдання 9. 3 поданими паронімами складіть речення (граматичну форму слів можна змінювати); значення незрозумілих слів запишіть у зошити, користуючись довідкою:

Дивний - дивовижний; житловий - жилий; замерзнути - змерзнути; кампанія - компанія; людний - людяний; пам'ятка - пам'ятник; дослідний дослідницький; дружний - дружній; зумовлювати - обумовлювати; покажчик - показник.

Довідка: Дивний - незрозумілий своїми якостями чи вчинками, кумедний; дивовижний незвичайний, гідний захоплення; житловий - пристосований для життя людей; жилий - заселений людьми, залюднений; змерзнути - відчути холод; замерзнути - загинути від холоду, перетворитися на кригу, стати твердим від холоду; кампанія - сукупність заходів, спрямованих на виконання певного завдання (посівна кампанія); компанія - група осіб, пов'язаних певними інтересами (телерадіомовна компанія); людний - про місце, де перебуває багато людей; людяний доброзичливий, чуйний, гуманний; пам'ятка - 1) предмет матеріальної чи духовної культури минулого (історична пам'ятка); 2) річ або об’єкт, що нагадує про когось чи про щось (лишити по собі пам'яткк); пам'ятник - скульптурна споруда на честь когось чи чогось; дослідний пов'язаний із науковими дослідженнями, призначений для ведення дослідів (дослідна лабораторія); дослідницький - прикметник до іменника дослідник (дослідницький погляд); дружний - який відбувається одночасно, спільно, злагоджено (дружний вигук); дружній - який виражає дружелюбність, прихильність, довіру (дружній потиск руки); зумовлювати - бути причиною чогось, спричиняти або викликати щось; обумовлювати - говорячи, заздалегідь визначати певні умови, ставити в залежність від них; показник - доказ, ознака, свідчення чого-небудь; покажчик 1) напис або знак, що вказуе напрямок руху; 2) довідковий список, доданий до книжки (бібліографічний покажчик).

Завдання 10. До поданих іншомовних слів доберіть українські відповідники, користуючись довідкою.

Анулювання; постскриптум; публіка; статус-кво; персона нон грата; репрезентувати; реприза; преамбула; пафос; феномен; куратор; дисгармонія.

Довідка: Післямова; становище в певний момент; представляти; небажана особа; глядачі; скасування; повторення; піднесеність; вступна частина чогось (договору, декларації тощо); розлад; унікальне, виняткове явище; наставник.

Отже, одним із найважливіших складників загальної культури особистості є культура мовлення, тобто здатність вільно володіти нормами сучасної літературної мови в різноманітних ситуаціях спілкування. Висока мовленнєва культура характеризується такими ознаками, як правильність, чистота, точність, логічність, ясність, різноманітність, багатство, естетичність, стилістична виразність і комунікативна доцільність. Формування високої культури мовлення студентів $€$ одним із головних завдань курсу «Українська мова 
(за професійним спрямуванням)». Вивчення цієї дисципліни є вкрай важливим, адже досконале знання мови підтримує в людині стан психологічної впевненості та рівноваги, дає відчуття стабільної духовної опори. Саме мова формує людину як інтелектуальний феномен, що здатний пізнавати, освоювати й творити навколишній світ. Нехтування культурою мовлення може спричинити знецінення самої мови; а знецінення мови призводить до знецінення іiі носіїв - мовців i, відповідно, знецінення цілої нації та іiї духовної культури.

\section{Література}

1. Голосовська Г. Г. Українська мова для всіх : [навч. посібник] / Г. Г. Голосовська. К. : ВЦ «Академія», 2013. $-216 \mathrm{c.}$

2. Дорошенко Т. С. Словник труднощів української мови / Т. С. Дорошенко. - Х. : Торсінг плюс, 2012. $-656 \mathrm{c}$.

3. Косенко Н. Я. Як правильно говорити українською : [практич. посібник] / Н. Я. Косенко, Т. М. Вакуленко. - Х. : КК «Клуб сімейного дозвілля», 2000. -237 с.

4. Масенко Л. Нариси 3 соціолінгвістики / Л. Масенко. - К. : Вид. дім «КиєвоМогилянська академія», 2010. - 243 с.

5. Мацько Л. І. Культура української фахової мови : [навч. посібник] / Л. І. Мацько, Л. В. Кравець. - К. : ВЦ «Академія», 2007. - 360 с.

6. Пономарів О. Культура слова. Мовностилістичні поради : [навч. посібник] / О. Пономарів. - К. : Либідь, 1999. - 240 с.

7. Шевчук С. В. Українська мова за професійним спрямуванням : [підручник] / С. В. Шевчук, І. В. Клименко. - [3-тє вид., випр. і допов.]. - К. : Алерта, 2012. - 696 с. Стаття надійшла до редакиї 17.09.2017 p. 